\title{
義肢装具領域の進歩と末来
}

\section{[Advances and Future in the Field of Prosthetics and Orthotics ]}

浅見豊子* Toyoko Asami

佐賀大学医学部附属病院リハビリテーション科

Key words：義肢／装具／ロボット／歴史／未来

\section{はじめに}

義肢は「切断により四肢の一部を欠損した場合 に，元の手足の形態または機能を復元するために 装着, 使用する人工の手足」, 装具は「四肢・体幹 の機能障害の軽減を目的として使用する補助用 具」とされている ${ }^{1,2)}$. 各々の使用により，失われ た外観や動きを補ったり，機能を改善する目的が あり, 義肢装具領域はリハビリテーション医療の大 きな役割を担っている，そして，近年はこの領域の 一部として, ロボットなどの先端医療機器も注目さ れている.

今回，義肢の歴史を遡りながら，義肢装具領域 の進歩と未来について述べたい.

\section{義肢の歴史}

古代エジプト時代には身体の欠損を補った義肢 が試みられ ${ }^{3)}$, 古代エジプトの都市テーベの墓地に 眠る中年女性には木製義足が装着されていたとさ れる ${ }^{4)}$.また，インドの医学書「リグ・ヴェーダ」 や, ヘロドトスの「歴史」には義眼や義肢の記載が ある ${ }^{5,6)}$. 紀元前 3 世紀頃の「Capua の棒義足」は

* 佐賀大学医学部附属病院リハビリテーション科

【連絡先】 T849-8501 佐賀県佐賀市鍋島 5-1-1

佐賀大学医学部附属病院リハビリテーション科

浅見豊子

E-mail : asamit@cc.saga-u.ac.jp

DOI : $10.2490 /$ jjrmc.57.1062

\section{(c) BY-NC-ND}

有名であるが, 紀元前 4 世紀頃のイオニア人の花 瓶や, フランスレスカール大寺院のモザイックにも 下腿の棒義足が描かれている。 これらの時代の義 足は, 足としての機能や形態はなく, むしろ杖に近 い物であったようである $(\text { 図 1 })^{7}$ )。義手の記録と しては, 第 2 ポエニ戦役（B.C.218～201 年）の時の Marcus Sergius の鉄製義手，現存する最古の義手 としてはドイッ人騎士 Getz von Berlichingen の義 手 (図 2) がある ${ }^{8)}$. 当時の義手は武器鍛冶職人が 製作していたとされている99.

一方，日本に扔いては，井上政重（1585～1661 年) が，ペレの外科書で義肢をみたのが始まり

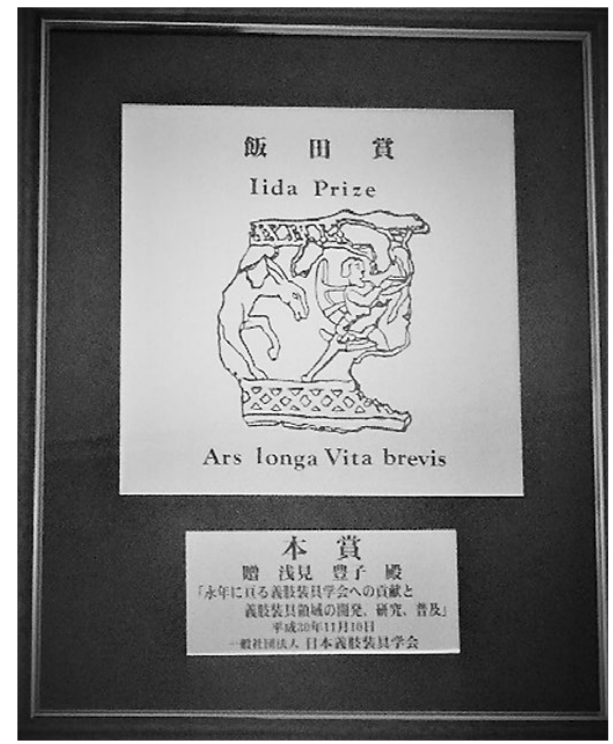

図１「下腿の棒義足の図柄」が組み込まれた日本 義肢装具学会飯田賞本賞記念盾 (筆者所有) 


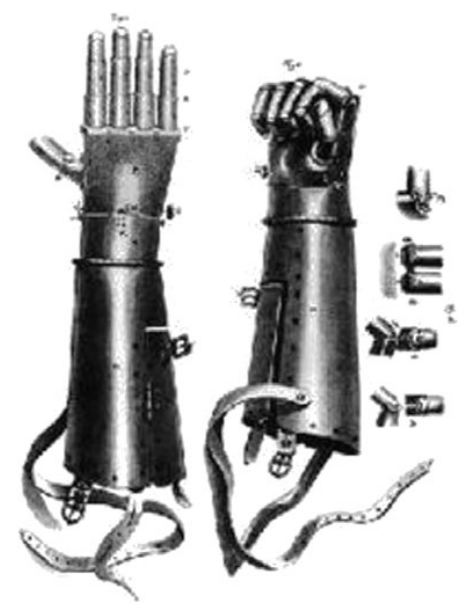

図 2 Getz von Berlichingen の義手

で10)，オランダ人医師に義肢を発注したものの, 実 際に使用はされなかった ${ }^{5,11)}$. 日本最古の義足は, 明治 10 （1878）年の西南戦争で西郷軍の負傷兵が 用いた在来型下腿義足とされている。 また，西郷 隆盛の長男菊次郎や大隈重信が切断となった際は 米国 A.A. マークス社製の義足を使用した (図3 $)^{5,6,11,12)}$. 米国人 Palmar の大腿義足は 1851 年ロンドン万国博で名誉賞を受賞してい $3^{5,6,11)}$. 幕末から明治初期に立女形として活躍 していた三世沢村田之助（1845～1878 年）は，19 歳の頃, 米国人医師 Hepburn により左下腿切断術 を受け，江戸の活人形師松本喜三郎作製の義足を 試みたが，最終的には米国 Selpho 社製の義足を装 着して再び舞台に立った (図 4) ${ }^{5,11,13)}$. 大正 7 （1818）年のシベリア出兵の際には同盟国チェコの 戦傷兵に聖路加病院で義肢が支給され, 恩賜の義 足は日清戦争（1894～1895 年）以後に負傷兵に支 給された. 日露戦争（1904～1905 年）の頃は，陸 軍大将乃木希典の乃木式義手（作業用能動義手) がつくられた ${ }^{14)}$. 最も古い義肢装具製作者は歯科 技工師の奥村義松で, 日本最初の義肢専門書は明 治 35 （1902）年に出版された鈴木祐一の『義手足 纂論』である ${ }^{15)}$.

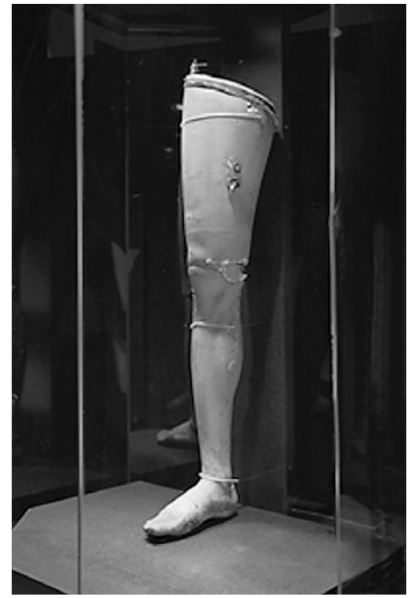

図 3 大隈重信記念館収蔵物の義 足 (米国 A.A. マークス社製/ 佐賀市大隈重信記念館提供)

第一次世界大戦の頃, ドイツに義肢検定所が創 立され, 義肢の検定, 標準化が行われた. この時 期の義手に Tannenberg 義手がある. また，義足 については, 第二次世界大戦後, 自己懸垂性を有 した木製の大腿四辺形ソケットの原型が用いられ た. 一方, 日本では, 第二次世界大戦時において ようやく第一次世界大戦時の義肢資料をもとに義 肢が製作された，それが，義足では鉄脚（ドリン ガー足）といわれる作業用大腿義足, 義手では Tannenberg 義手を原型とする陸軍十五年式義手 という作業用義手であった. 敗戦後は竹製の義足 も使用された5, 6,11).

\section{義肢の進歩}

義肢の製作についてみると, 1960 年代後半, オー ダーメイドの個別製作から部品を組み上げてつく るモジュラーシステムが導入された，1970 年代は, 関節構造機構の部品が製作されるようになり, 1980 年代初期には, 関節機能のある継ぎ手が開発 され，義肢の継手にマイクロプロセッサーが用いら れるようになった. また, 最初のエネルギー蓄積型 足部である Seattle-Foot が開発・商品化された。 


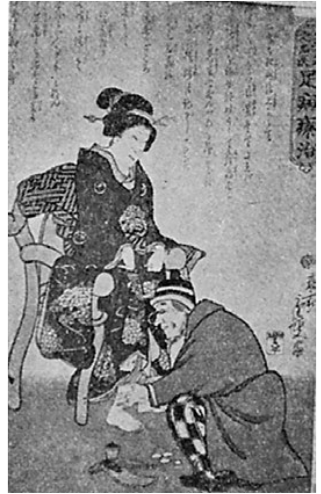

図 4 歌舞伎役者, 三世沢村田之助

1987 年には, Iceland の Ossur Kristinsson により シリコーンライナーシステムが開発され（図 5), 1995 年には Osseo Integration（骨直結型義足）研 究が開始された. 2003 年にはメキシコの Marlo Ortisにより MAS ソケットが考案された．義手に ついては, 第二次大戦後に体外力源の開発が進め られ，ドイツの圧縮炭酸ガス圧力作動型義手がサ リドマイド児に適応され，1960 年後半から 1970 年 初期にかけて筋電制御の電動義手が実用化され, オーストリア, ドイツ, イタリア, 米国で商品化さ れた ${ }^{16)}$.

\section{義肢装具領域のテクノロジー}

戦争により研究が進んだのが軍事産業用ロボッ トである。 米国 Boston Dynamics 社の Big Dog や Atlas などが開発された. BiOM 社は iWalk とい う傾斜面でも自動角度調整が可能である高機能な 義足を開発した ${ }^{16)}$.

日本でも, 現在, 産業用ロボットから医療用ロ ボット，介護用ロボットと多種多様のロボットが開 発され応用されてきている17, 18).

医療分野では，「ロボットスーツ HAL (HAL)」 がリハビリテーションロボットとして注目さ $れ^{19,20)}$, 医療用モデルは 2015 年 11 月 25 日に装 着型医療ロボットとしては初めて医療機器として

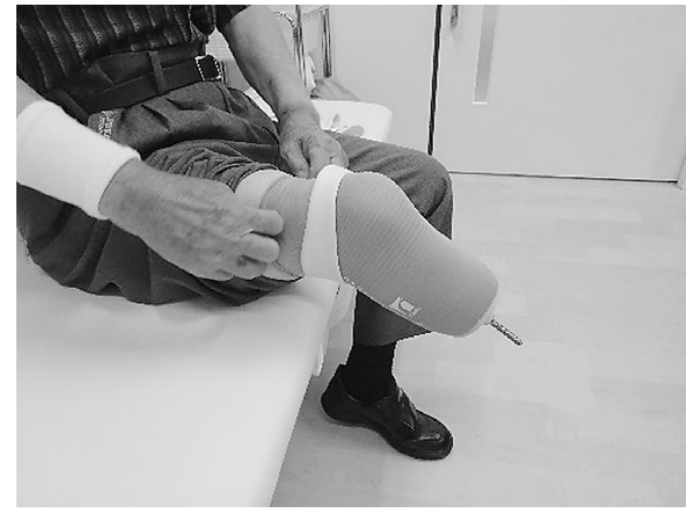

図 5 ピン付きシリコーンライナー装着の様子

の製造販売承認を受け, 2016 年 4 月に神経難病の 8 疾患に対しての保険に収載された，その後はさ らに多くのリハビリテーションロボットが医療機器 として承認された，また，『脳卒中治療ガイドライ ン 2015』においては ${ }^{21)}$, 上肢機能障害や歩行障害 などの項目にロボットに関する記載が追加され, 2020 年 4 月の医療報酬改定では, リハビリテー ション総合計画評価料において運動量増加機器加 算として, 発症より 2 カ月までの脳卒中または脊䯣 障害の急性発症に伴う上肢または下肢の運動機能 障害を有する患者（脳卒中または脊髄障害の再発 によるものを含む) に対して, 月 1 回に限り 150 点 の所定点数への加算が新設された ${ }^{22,23)}$. 一方, 介 護分野においては，(1)移乗介助，(2)移動支援，(3) 排泄支援，(4)認知症の方の見守り，(5)入浴支援な どを目的としたさまざまなロボットが開発・導入さ $れ^{24)}, 2018$ 年 4 月の介護報酬改正においては介護 支援ロボットの 1 つである見守り機器が夜勤職員 配置加算の緩和条件になった ${ }^{25)}$.

当院では, リハビリテーションロボットを活用し た「ロボットリハビリテーション外来」を全国に先 駆けて開設したが26,27)，その流れは2001 年に導 入した筋電義手に始まる ${ }^{28)}$. 2011 年のロボット スーツ HAL 福祉用 (HAL) と Honda 歩行アシス ト (Honda アシスト) の導入, その後は NESS 


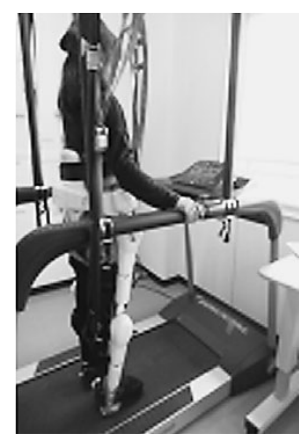

$\mathrm{HAL}$

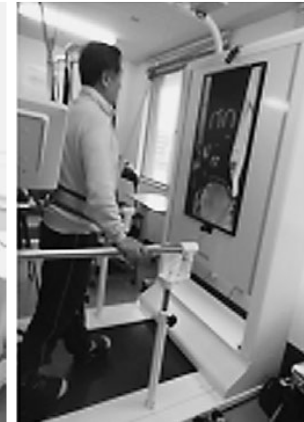

TOYOTA

ウェルウォーク

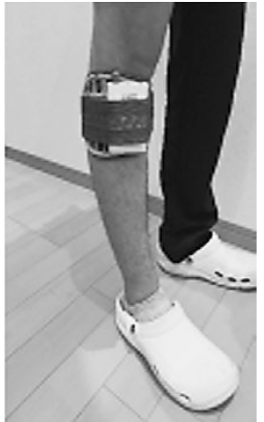

ウォークエイド

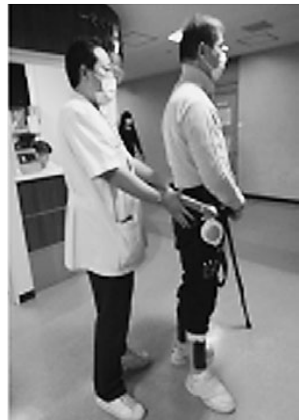

Honda 歩行アシスト

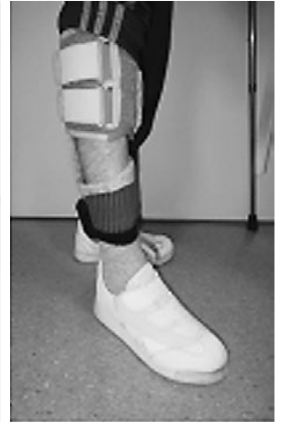

NESS L300

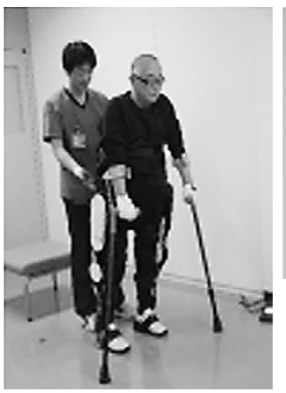

Free Walk

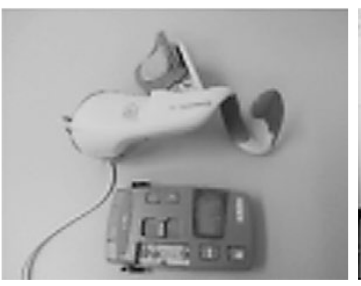

NESS H2OO

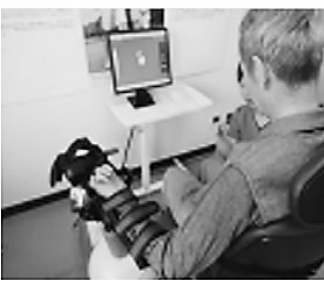

Reo Go J

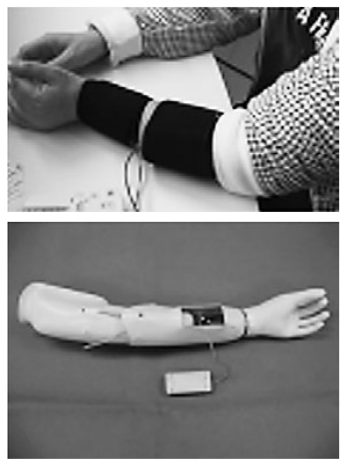

図 6 当院ロボットリハビリテーション外来における種々のロボット

H200 (ハンド・リハビリテーション・システム), NESS L300 (フットドロップ・システム), 歩行神経 筋電気刺激装置ウォークエイド, GEAR（Gait Exercise Assist Robot)，上肢用ロボット型運動訓練 装置 ReoGo-J, FREE Walk, IVES (Integrated Volitional control Electrical Stimulator) なども導 入し、これらリハビリテーションロボット治療と磁 気刺激療法やボッリヌス療法などを併用したリハ ビリテーション治療の取り組みを行ってきた (図 6) ${ }^{29-33)}$.

介護ロボットについては, 2017 年より佐賀県介 護ロボット事業に取り組んでいるが34), そこでは 被介護者の自立支援を助け介護量を減らすための 「自立支援用ロボット」と，して Honda アシスト， GEAR, ウォークエイド, 認知トレーニングエルゴ メーターコグニバイクを, 介護者の身体を直接補
助し介護者の介護負担を軽減するための「介護者 用ロボット」として HAL 介助用, 移乗サポートロ ボット Hug, 見守りケアシステムを使用し検討して きている.

このように, 医療用・介護用ロボットに約 20 年 にわたりかかわってきた今, ロボットの現状とこれ からについての私見を次に述べたい.

リハビリテーション治療の効果は, 高密度で高 頻度の治療を行うほどよりよい効果が得られると 考えられるが, マンパワーの面や医療経済の面か らすると, 高頻度の治療を行うには限界がある. そこで，ロボットを用いることで高密度にし，低頻 度であっても効果的な成果を出すことがこれから のリハビリテーション治療のあり方ではないかとの 考えに至り, 当院ではその方策について検討して いる，ロボットが高密度の治療を行うことのできる 


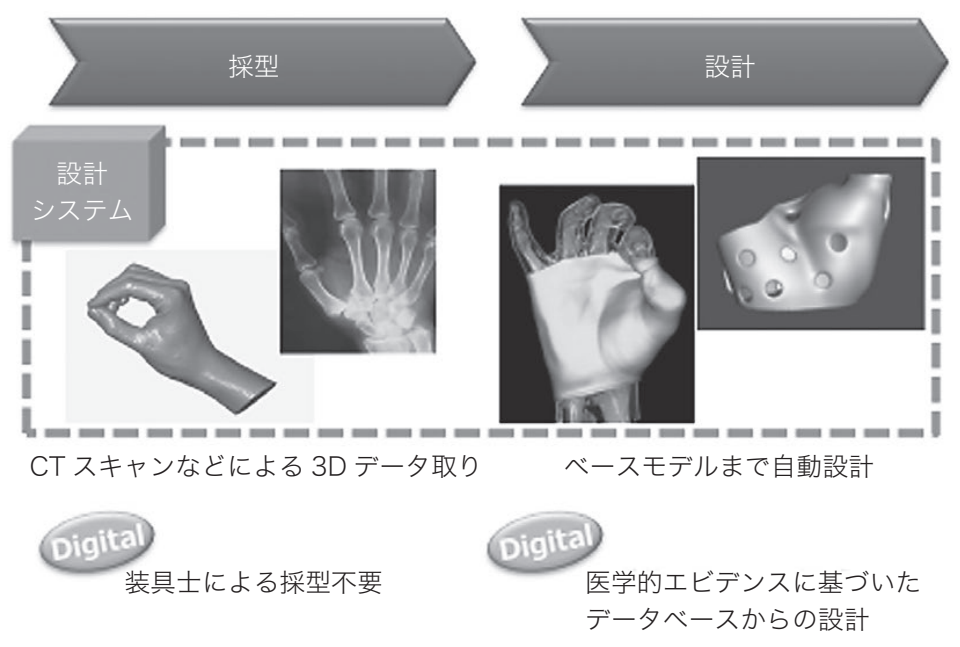

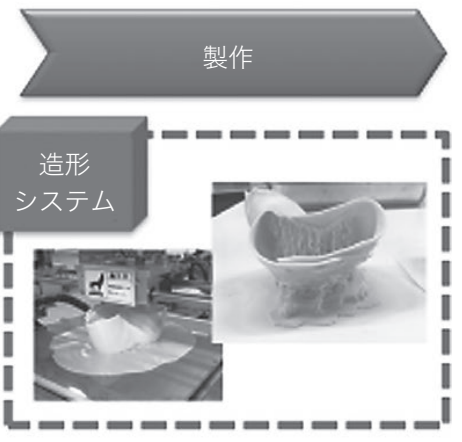

半製品まで 3D プリント

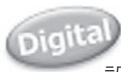

設計システムとの連動により プリンタを自動的に始動

\section{図 7 義肢装具製作のデジタル化（東名ブレース提供）}

機能の 1 つとして, 負荷調節したうえでの反復運 動を容易にすることがあるが，これにより運動の確 実な質と量が確保できることになる。この点は, 2020 年 4 月の診療報酬加算にもつながっている4). また，ロボットが備えているデイスプレーや効果音 を利用した視覚的フィードバック機能や聴覚的 フィードバック機能は, 患者やスタッフへのより客 観的な情報提供に役立つ。これは，病態に応じた リハビリテーション治療につなげられる。つまり, リハビリテーション治療の時間は同じであってもよ り質の高い, すなわち筆者が高密度と呼んでいるリ ハビリテーション治療をロボット使用により提供で きることになる，そして，この一端は当院の治療成 果にも表れている29).

しかし，課題としては，ロボットを使いこなす術 の標準化ができていないことであると思っている. ロボットの機能, 操作方法, ロボット使用による治 療プラン作成などを熟知し臨床使用する技術を習 得するには, それなりの時間を要するため, 実際の ところ，一部のリハビリテーションスタッフしか対 応できていない現状がある。このことを解決する ために必要なのが, 医師, リハビリテーションスタッ フ, 義肢装具士，エンジニアなど関連職種における
卒前・卒後におけるリハビリテーションロボット治 療の教育体制であると考える.

さらには，導入費用の問題もある．諸外国（米 国, 英国, ドイッ,ノルウェー) においては公的保 険償還が認められている。しかし，日本において は, 一部ロボットに特定の疾患に対する保険適応 と一部保険加算などがあるにすぎない，今後さら に公的な制度としての保険適応や保険加算，ある いは障害者自立支援法に基づく補装具としての認 可などの制度整備が進み, 患者の自己負担軽減や 施設へのロボット普及推進につながることが望ま れる.

そして, これからの義肢装具領域に期待される 分野の 1 つが, 3D デジタル技術の義肢装具領域へ の導入である ${ }^{35)}$. 利点としては, X 線画像などと スキャンデータ合成による迅速性製作・適合性向 上により治療効果が向上する．3D スキャナが従来 のギプス採型より対象者の身体的負担を軽減し, また複合材料などによりさまざまなデザインが可 能なためデザイン性が向上する，さらに，デジタル データ分析による製作・適合にかかわるエビデンス が構築できる. 義肢装具士の働き方改革を推進す るなどにもつながるものとされている. しかし，一 


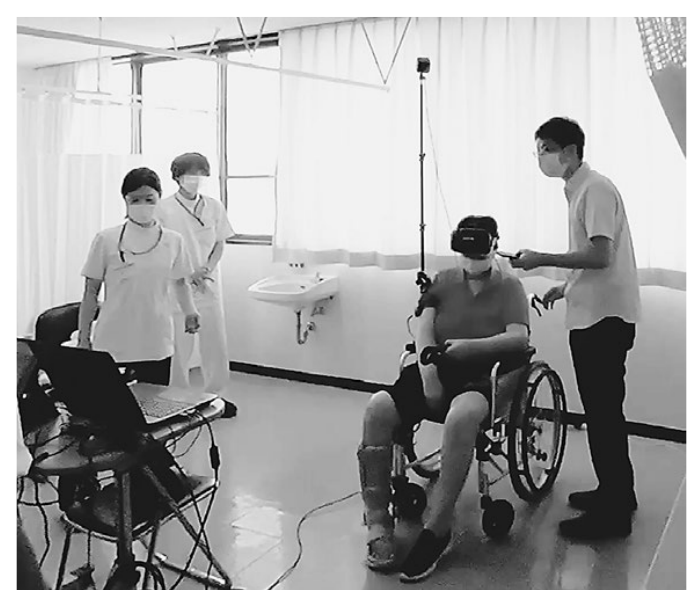

図 8 medi VR カグラの使用風景

方で, 対象者への医療・福祉効果のエビデンス, 3D スキャナによるスキャン行為と現状の義肢装具 士法における採寸・採型の定義との整合性の問題, $3 \mathrm{D}$ プリンタ造形義肢装具の安全性の保障, 3D CAD-CAM/printing による製作の定義化，3D デ ジタル技術導入に向けたアセスメント・モラルなど の教育などの問題も生じてくる（図 7).

別の技術としては, virtual reality（VR）の導入 である，例えば, medi VR カグラは非言語コミュ ニケーションにより言葉で説明しなくとも, 動作方 法をマルチチャネルバイオフィードバックにより直 感的に理解可能とする機器である (図 8) ${ }^{36)}$. 近年 のリモート医療, 今な㧍続いているコロナ禍の医療 の中で, 非常に着目すべきものであると考えてい る.

\section{おわりに}

リハビリテーション治療の処方を行う医師は，処 方内容において, 義肢装具領域部分の処方も適切 に行う必要がある。 そして, 義肢装具領域の機器 を使用する医療職種はこれらを適切に操作する必 要がある，そのためにも，義肢装具領域における さまざまな項目の標準化が進み, ロボットなど最先
端医療機器を含めた義肢装具領域治療のガイドラ インが作成されることが期待される，それが，これ からの義肢装具領域のさらなる発展と医療や介護 におけるリハビリテーション治療の成果を生み出 すものではないかと思っている.

\section{COI 開示}

浅見豊子：佐賀県事業，帝人 (株)，本田技研工業（株）, トヨ夕自動車（株）

\section{文献}

1）日本リハビリテーション医学会 編: リハビリテーショ ン医学・医療用語集第 8 版. 文光堂, 東京, $2019: \mathrm{p}$ 225

2）日本規格協会 編：JIS ハンドブックー38 高齢者・障 害者等アクセシブルデザイン，日本規格協会, 東京, 2018 : pp 2440

3) van de Veen PG : An investigation of design criteria of modular endoskeletal lower limb prostheses. S.I.s.n. 1989

4) Jung C : Die erweiterung der mensch-prothesenkonsrellation: eine technografische analyse zur intelligenten beinprothese. Technical University Technology Studies Working Papers : TUTS-WP1-2004. Institut fur Soziologie, 2004

5）武智秀夫：手足の不自由な人はどう歩んできたか一 人権思想の変遷と義足・装具の進歩. 医歯薬出版, 東京, $1982:$ p 182

6）武智秀夫, 明石 謙：わが国の義肢の変遷. 義肢. 医学書院, 東京, 1991：p 292

7) Edward JW : Artificial Limbs American Academy of Orthopaedic Surgeons. Orthopaedic Appliances Atlas : A Consideration of Aids Employed in the Practice of Orthopaedic Surgery. Vol 2, Ann Arbor, $1960: \mathrm{p} 2$

8）Loffler L 原著, 平澤泰介 訳: 義手一その起源と発達. パシフィックサプライ, 大阪, 1986: p 192

9）武智秀夫, 明石 謙, 児玉俊夫 監：II 義手の歴史. 義手. 医学書院, 東京, $1972 ：$ pp 6-29

10) Edward JW : Artificial Limbs American Academy of Orthopaedic Surgeons.Orthopaedic Appliances Atlas : A Consideration of Aids Employed in the Practice of Orthopaedic Surgery. Vol 2, Ann Arbor, $1960:$ p 7

11）武智秀夫 : わが国の義肢装具の歴史. リハビリテー ション研究 $1993 ; 75: 30-33$

12) Marks AA. Kato T : 大隈重信文書. 早稲田大学 蔵, 東京, $1895 ;$ p 282

13）南條範夫：三世沢村田之助. 文藝春秋社, 東京, 1989 : pp 179-180

14）武智秀夫：日露戦争における切断 - 義肢と乃木式義 手. 日本医史学雑誌 $1982 ； 28: 338-351$ 
15）鈴木祐一：義手足纂論．南江堂, 東京, 1902

16）田澤英二：義肢の進歩の歴史とこれから．日本義肢 装具学会誌 $2014 ； 30 ： 105-112$

17）ロボット革命実現会議：ロボット新戦略. 経済産業 省発表資料. 2015；pp 63-70

18）経済産業省：「ロボット政策研究会中間報告書（案） 一ロボットで拓くビジネスフロンティアー」について. 2004. Available from URL : http://www.zenmoku. jp/moku_kankei/robottoseisakukenkyuukai.html

19）山海嘉之：サイバニクスを駆使した HAL（Hybrid Assistive Limbs）最前線. 分子脳血管病 $2012 ； 11$ ： 261-270

20）中島 孝: 脳, 脊髄, 神経・筋疾患に対する $\mathrm{HAL}^{\circledR} の$ 医療用応用の基本戦略一医師主導治験の経験から. 臨床評価 $2013 ; 42: 31-38$

21）日本脳卒中学会脳卒中治療ガイドライン［追補 2019］委員会 編：脳卒中治療ガイドライン 2015（追 補 2019)。協和企画, 東京, 2019

22）厚生労働省：令和 2 年度診療報酬改定説明資料等に ついて. 2020. Available from URL : http://www. mhlw.go.jp/stf/seisakuunitsuite/bunya/0000196352 _00001.html

23）厚生労働省：第 451 回中央社会保険医療協議会 : 総 会議事録. 2020 年 2 月 7 日

24）厚生労働省：「介護ロボットの開発・実用化を支援し ます!」パンフレットデータ. Available from URL : https://www.mhlw.go.jp/content/12300000/427.pdf

25）厚生労働省：平成 30 年度介護報酬改定の主な事項 について. Available from URL : http://www.mhlw. go.jp/file/06-Seisakujouhou-12300000-

Roukenkyoku/0000196991.pdf

26）浅見豊子：ロボットリハ外来開設の意義と上肢ロボッ トの有用性. 月刊新医療 $2015 ； 11: 96-98$

27）浅見豊子：ロボットリハビリテーション外来と宜椎疾 患. 脊椎脊髄ジャーナル $2016 ； 29 ： 729-734$
28）浅見豊子：筋電義手における導入と活用のポイント. Jpn J Rehabil Med 2018 ; 57 : 227-233

29) Asami T, Kitajima M, Nanri Y, Murata K, Sato T : Case report on long-term, continuous improvement of walking ability as a result of botulinum toxin injection therapy and low-frequency rehabilitation with HAL. Int J Phys Med Rehabil 2016 ; $4: 3$

30）大畑光司：「歩行アシスト」を用いたリハビリテーショ ン. Clinical Engineering $2014 ; 25: 149-153$

31）松永俊樹, 島田洋一: 神経疾患に対するリハビリテー ション工学. Monthly Book Medical Rehabilitation $2012 ; \mathbf{1 4 1}: 33-36$

32) Everaert DG, Stein RB, Abrams GM, Dromerick AW, Francisco GE, Hafner BJ, Huskey TH, Munin MC, Nolan KJ, Kufta CV : Effect of a foot-drop stimulator and ankle-foot orthosis on walking performance after stroke : a multicenter randomized controlled traial. Neurorehabil Neural Repair 2013 ; 27 : 579-591

33) 平野 哲, 才藤栄一, 加藤正樹, 山田純一, 井元大 介：歩行練習ロボット. 理学療法ジャーナル 2015 ; 49:845-852

34）佐賀大学：佐賀県介護ロボット導入モデル事業所の 募集について. 2017. Available from URL : https:// www.saga-u.ac.jp/koho/common/20170928IX451

35）斎藤亮真, 郷 貴博, 東江由起夫 : $3 \mathrm{D}$ スキャナーを 用いた下腿義足ソケットと切断端の形状比較につい て. 新潟医療福祉学会誌 $2019 ; 19: 46-46$

36) Hara M, Kitamura T, Murakawa Y, Shimba K, Yamaguchi S, Tamaki M : Safety and feasibility of dual-task rehabilitation program for body trunk balance using virtual reality and three-dimensional tracking technologies. Prog Rehabil Med 2018 ; 3 : 20180016 